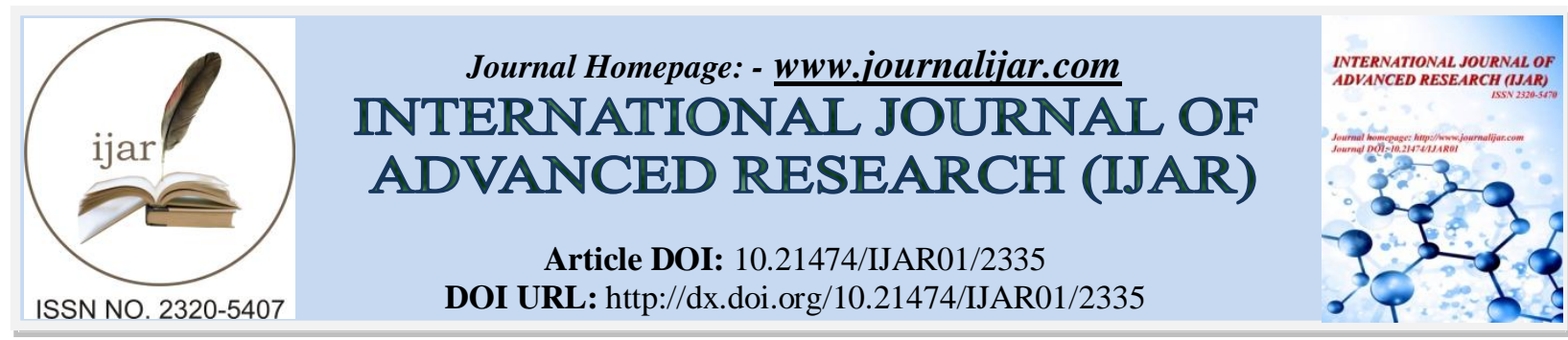

RESEARCH ARTICLE

\title{
A STUDY TO ASSESS THE KNOWLEDGE REGARDING ANEMIA AMONG ADOLESCENT GIRLS IN V.O.C. HIGHER SECONDERY SCHOOL AT KOTUCHERRY, KARAIKAL.
}

Asst.prof / hod of obg dept, Vinayaka mission's college of nursing Karaikal.

\section{Manuscript Info}

Manuscript History

Received: 30 September 2016

Final Accepted: 30 October 2016

Published: November 2016

\section{Abstract}

A study to assess the knowledge regarding anemia among adolescent girls in V.O.C. higher secondary school at Kotucherry. The objectives are 1.to assess knowledge on anemia among adolescent girl, 2. to find the association between the knowledge on anemia among adolescent girls with selected demographic variables. Data was collected from 70 adolescent girls by using convenient sampling. Data were analyzed by descriptive and inferential statistics. The study result shows that the maximum $43(61.4 \%)$ adolescent girls are having inadequate level of knowledge regarding anemia, $26(37.1 \%)$ adolescent girls are having moderate level of knowledge regarding anemia and1 (1.5\%) adolescent girls are having adequate level of knowledge regarding anemia.

Copy Right, IJAR, 2016,. All rights reserved.

\section{Introduction:-}

Adolescent period is defined by the WHO as the period of life spanning the age between 10 to 19 years. This is the formative period of life when the maximum amount of physical, psychological, and behavioral changes take place. This is a vulnerable period in the human life cycle for the development of anemia, which has been constantly neglected by public health programs. Anemia is one of the India's major public health problems affecting all societies, especially most prevalence among adolescent girls. WHO (2001): stated that peak prevalence of anemia occurs among females during adolescence. Adolescent period have been recognized as a special period in the life cycle that require specific and special attention. There are direct linkage between poverty and anemia. Adolescent girls caught in this vicious cycle are the young mothers of $21^{\text {st }}$ century. They are deprived of the basic rights to health, education, development and independences. Adolescent girls scheme is a special intervention programme for girls between 13 to 18 years of age to meet the special needs in nutrition education and development. Adolescent health is one important thrust of the new reproductive and child health programme.

\section{Statement of the problem:-}

A study to assess the knowledge regarding anemia among adolescent girls in V.O.C. higher secondery school at Kotucherry, Karaikal.

\section{Objectives:-}

- To assess the knowledge regarding anemia among adolescent girls.

- To find the association between the knowledge regarding anemia among adolescent girls with selected demographic variables. 


\section{Methodology:-}

The research design adopted for this study was descriptive design. The study was conducted in a government girls high school at kottucherry, karaikal. The study population for this study was all the adolescent girls. The sample for the study were all the adolescent girls between the age of 16-18 years, studying in V.O.C Government higher school at kottucherry, karaikal. 70 Adolescent girls were selected for this study. Convenient sampling technique method was used to select the adolescent girls for collecting information regarding nutritional anemia among adolescent girls.

\section{Data collection Procedure:-}

After getting written permission from head master of Government high school kottucherry, informed oral consent was obtained from the study participants. Data was collected from $9^{\text {th }}$ standard students. 70 adolescent girls were selected using convenient sampling technique.. The self structured questionnaire on nutritional anemia was used to collect the data from the adolescent girls. It consists of two sections.

Section I: It has items related to demographic variable such as age, religion, parent's occupation, family income, type of family, source of information, birth order, family history of anemia.

Section II: It consist of 25 question related to knowledge on nutritional anemia which includes definition, causes, signs and symptoms, treatment, complication and prevention. For each correct response the score awarded was ' 1 ' and for wrong response the score awarded was 'zero' total score was 25.

The data collected from 70 samples were analyzed using descriptive and inferential statics.

\section{Results and discussions:-}

- The findings of the study were out of 70 samples 61 (87.1\%) adolescent are at the age 16 years, $9(12.9 \%)$ are 17 years.

- Regarding the religion the maximum 65 (92.9\%) adolescent girls are Hindus, 4 (5.7\%) adolescent girls are Christians and minimum 1 (1.4\%) adolescent girl are Muslim.

- Based on the fathers occupation the maximum 30 (42.9\%) fathers are self employee, $29(41.4 \%)$ fathers are comes under others, $6(8.6 \%)$ fathers are government employee and minimum $5(7.1 \%)$ fathers are private employee.

- According to the family monthly income, maximum 24 (34.3\%) adolescent family monthly income is below Rs. 1000, 21 (30.0\%) adolescent family monthly income between Rs. 1000-5000, 16 (22.9\%) adolescent family monthly income is Rs. 5000-10,000 and minimum 9 (12.9\%) adolescent family monthly income is above Rs. 10,000 .

- Based on the mothers occupation the maximum $52(81.4 \%)$ adolescent girls mother are private employee, 9 (12.9\%) adolescent girls mother are self employee, 4 (5.7\%) adolescent girls mother are government employee and none of them come under house wife.

- According to the type of family, maximum 64 (91.4\%) adolescent girls are nuclear family, 4 (.57\%) adolescent girls are joint family and minimum $2(2.9 \%)$ adolescent girls are extended family.

- According to the source of heath information, maximum $38(54.3 \%)$ adolescent girls are getting health information from government hospital, 31 (44.3\%) are getting health information from PHC and minimum 1 $(1.4 \%)$ are getting health information from sub center.

- According to information about anemia, maximum 44 (62.9\%) adolescent girls are received information from health professional, $19(27.1 \%)$ adolescent girls are non exposure to any information, $4(5.7 \%)$ adolescent girls are received information from others and minimum $3(4.3 \%)$ adolescent girls received information from medias.

- According to the family history, maximum $62(88.6 \%)$ of adolescent girls family members are free from anemia and minimum $8(11.4 \%)$ of adolescent girls family members are suffering from anemia. 


\section{Percentage distribution of adolescent girls based on their level of knowledge regarding anemia.}

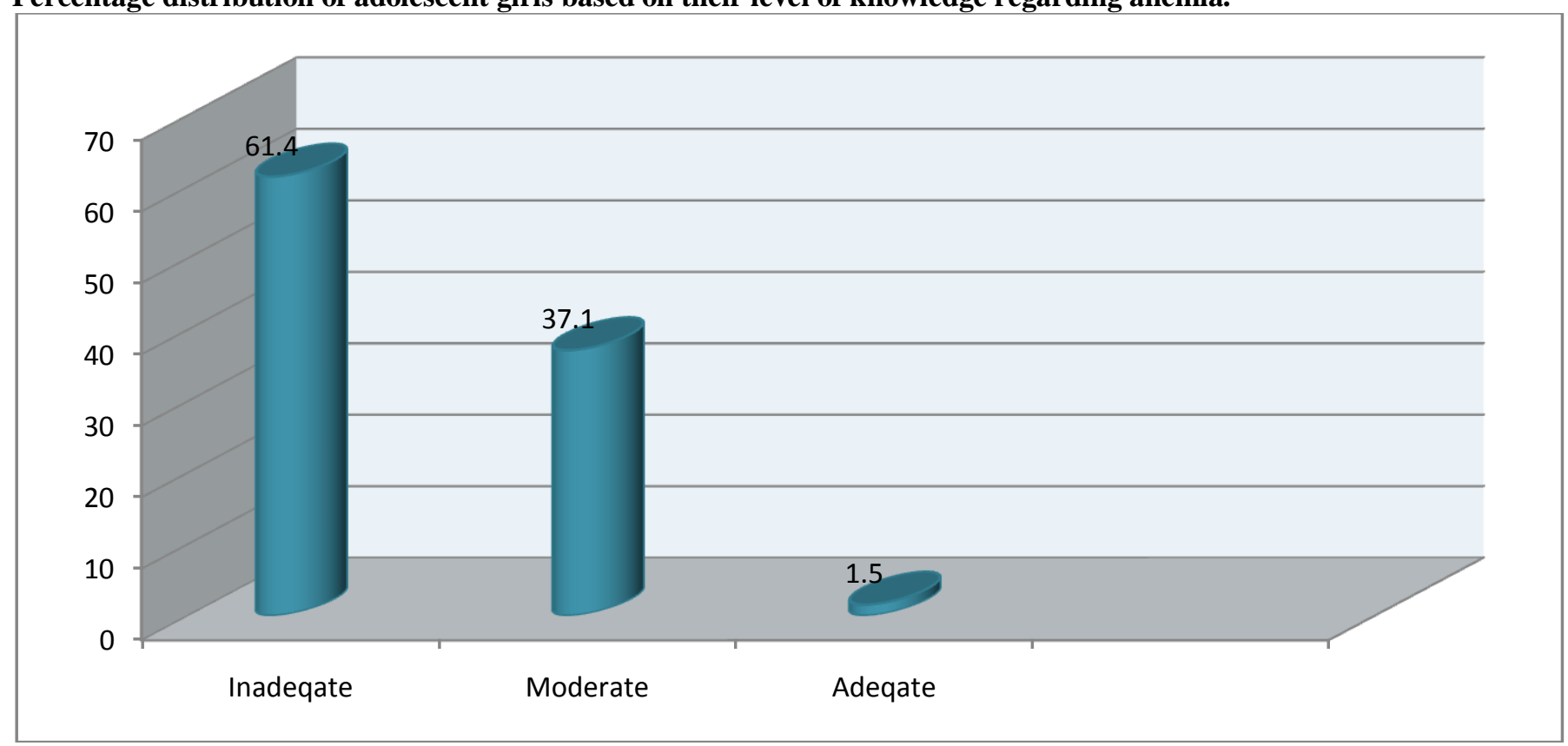

- The finding shows that the maximum $43(61.4 \%)$ adolescent girls are having inadequate level of knowledge regarding anemia, $26(37.1 \%)$ adolescent girls are having moderate level of knowledge regarding anemia and1 $(1.5 \%)$ adolescent girls are having adequate level of knowledge regarding anemia.

- With regard to knowledge on definition and classification of nutritional anemia, the present study revealed that $34 \%$ of samples had adequate knowledge. The majority $40 \%$ of samples ha moderately adequate knowledge and only $26 \%$ of the samples had inadequate knowledge.

- Regarding knowledge on causes and risk factor of nutritional anemia, the result showed that only $6 \%$ of sample had adequate knowledge, $18 \%$ of sample had moderately adequate knowledge and majority $76 \%$ of sample had inadequate knowledge.

- Regarding knowledge on signs and symptoms and investigation of nutritional anemia, the result showed that the majority $46 \%$ of sample had adequate knowledge. Only $26 \%$ samples had, moderately adequate knowledge and $28 \%$ of sample had inadequate knowledge.

- There was significant association between level of knowledge with selected demographic variable such age, religion, occupation, income, type of the family, and birth order. This shows that age, religion, occupation and their income has impact on the knowledge level of adolescent girls on nutritional anemia.

\section{Recommendations:-}

- The similar study can be replicated with a large sample

- A comparative study can be conducted between rural and urban adolescent school children.

- The structured teaching programme regarding knowledge on nutritional anemia can be conducted among adolescent girls.

- A study to assess prevalence, risk factors of nutritional anemia can be conducted among adolescent girls.

\section{Bibiliography:- books.}

1. Dorothy. R. Marlow, A . RADDING. Text book of pediatrics. Pholadelphia; W. B Saunders company, page number 649-652.

2. Jessie M, chellapa(200).Pediatric nursing, Banglore; Gaianana Book publishers, $1^{\text {st }}$ edition, page no.269-277.

3. Mahtal S. Bamji et al,(1996). Text book of human nutrition. New Delhi; Oxford and TBH publishers, co.pvt. Ltd., page number.267-277.

4. Saldu M.J,el al,(1999). Encyclopedia of Human Nutrition. Volume I ,haecourt Brace and company, publishers, Lomden, page number 24-28,81-84. 
5. WHO (2002). The Management of nutrition in major emergencies, Geneva; A.I.T.B.S. PUBLISHERS, Delhi,page number. 16-21.

\section{Journals:-}

- Agarval et al," Anemia prophylaxix in adolescent school girls biweekly or daily iron folate supplementation. Journal of India pediatrics, Aprial(2003),40(4); page number,296-301.

- Bajpai Aprana. "A study on prevalence on Anemia among adolescent children in selected schools of Delhi and to evaluate the effectiveness of health programme on prevention and control of Anemia." Choithram college of nursing, sovenier (2001) , page number 143-148.

\section{Net reference:-}

- $\quad$ http://www.wisegeek.com

- http://www.acog.org/wiki/middle age.infohttp://www.jehp.net

- http://www.tandf.online.com

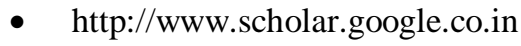

- http://www.journals.iww.com. 